九州大学学術情報リポジトリ

Kyushu University Institutional Repository

\title{
Effects of Nitrogen Application on Growth and Yield of Nitrate-Tolerant Mutants of Soybean
}

Hussain, Abul Kashem Mohammed Anwar

Laboratory of Plant Nutrition, Faculty of Agriculture, Kyushu University

Yamakawa, Takeo

Laboratory of Plant Nutrition, Faculty of Agriculture, Kyushu University

Ikeda, Motoki

Laboratory of Plant Nutrition, Faculty of Agriculture, Kyushu University

Ishizuka, Junji

Laboratory of Plant Nutrition, Faculty of Agriculture, Kyushu University

https://doi.org/10.5109/24004

出版情報：九州大学大学院農学研究院紀要. 37 (2)，pp.133-138，1992-12. Kyushu University バージョン：

権利関係 : 


\title{
E ffects of $\mathrm{N}$ itrogen Application on $\mathrm{G}$ rowth and $\mathrm{Y}$ ield of $N$ itrate-T olerant $M$ utants of Soybean
}

\author{
Abul Kashem M ohammed Anwar H ussain, Takeo Yamakawa, \\ M otoki I keda and J unji I shizuka
}

Laboratory of Plant Nutrition, Faculty of Agriculture, Kyushu University 4602, Fukuoka 812, Japan

(Received July 13, 1992)

\begin{abstract}
A field experiment was conducted using nitrate tolerant mutants of soybean (Glycine max IL.1 Merr.) ntsl116 and nts1007 and its parent cv. Bragg as test crops to study the effects of nitrogen application on growth and yield parameters. Nirtogen was fertilized as ammonium sulfate at the rate of $100 \mathrm{~kg} \mathrm{~N} / \mathrm{ha}$. Samples of each line with and without nitrogen application was harvested at flowering, pod filling and maturity stages. Nts1007 in growth parameters were inferior to Bragg and ntsll16. The pod numbers of Bragg and nts1116 at pod filling stage decreased with the application of nitrogen but nts1007 showed no difference. Nts mutants nodulated much more than the parent cultivar Bragg at all growth stages in non-N-applied plants. Nodulation of nts1007 was the highest at all stages in both $\mathrm{N}$ - and non-N-applied plants. The nodule size of Bragg was depressed sharply with nitrogen application followed by nts1116. In case of nts1007, however, there was no remarkable difference in the nodule size between $\mathrm{N}$ - and non- $\mathrm{N}$-applied plants. The grain and total dry matter production were the highest in Bragg followed by nts1116 and nts1007. Nitrogen application depressed both grain and total dry matter production in Bragg and ntsl116 but nts1007 revealed the increased values.
\end{abstract}

\section{INTRODUCTION}

Regulation of symbiotic nitrogen fixation in legume takes place at all stages of nodule development, affecting nodule initiation, nodule growth, development of nitrogen fixing activity and the onset of nodule senescence (Streeter, 1981 ; Carroll and Gresshoff, 1983). Symbiotic development is tightly regulated by both internal (autoregulatory) and environmental factors. Symbiotic nitrogen fixation of legumes is depressed in the presence of combined nitrogen, nitrate or ammonia. Carroll et al. (1985) isolated several independent soybean mutants that continued to nodulate in the presence of nitrate and termed as nitrate-tolerant symbiosis (nts) mutants. They nodulated abundantly compared with the parent cv. Bragg in the absence or presence of combined nitrogen and appeared to have an altered autoregulatory system governed by shoot factors (Gresshoff et al., 1985; Delves et al., 1986).

Haider et al. (1991) studied nts mutants of soybean, nts1116 (hypernodulating) and nts1007 (supernodulating) and their parent cv. Bragg grown hydroponically under controlled environmental conditions up to 44 days of plant growth and concluded that the repression of vegetative growth in nts1007 compared with Bragg and nts1116 was related to higher consumption of photosynthates by nodule growth or the high ureide production of plant associated with the super-abundant nodulation. In the present 
study, the growth and yield parameters of the nts mutants were compared to those of the parent cv. Bragg in two nitrogen levels at different stages under natural field conditions; and the genetic traits such as nitrate tolerance and heavily abundant nodulation were examined from an agronomic point of view.

\section{EXPERIMENTAL}

\section{Plant growth}

Soybean (Glycine max L. Merr.) cultivar Bragg (wild-type, nod+, fix+) and its mutants ntsll16 (nitrate tolerant, hypernodulating, nod++, fix+) and nts1007 (nitrate tolerant, supernodulating, nod ${ }^{+++}$, fix + ) were used for the experiment. The nts mutants and cv. Bragg were given by Dr. P. M. Gresshoff, The University of Tennessee and Dr. K. Igita, Kyushu Agricultural Experiment Station, respectively.

Plant growth was conducted in gray lowland soils of the Kyushu University farm, on the northern flooded plain of Fukuoka prefecture (latitude $33^{\circ} 38^{\prime} \mathrm{N}$, longitude 130" 28 , E). The initial soil $\mathrm{pH}$ (soil:water ratio was 1:2.5) of field ranged between 4.9 to 6.6. The total nitrogen (Eastin, 1978) and available phosphorus (Troug, 1930) contents of the soil were $0.18 \%$ and $415 \mathrm{ppm}$, respectively.

To improve the soil condition, $300 \mathrm{~kg} / \mathrm{ha}$ of calcium magnesium carbonate, $3 \mathrm{t} / \mathrm{ha}$ of barnyard manure and $200 \mathrm{~kg} \mathrm{P}_{2} \mathrm{O}_{5} /$ ha of fused phosphate were plowed in the experimental plot.

The plots consisted of five rows for each cultivar, $5.0 \mathrm{~m}$ in length and $3.5 \mathrm{~m}$ in width. The row width and intra-row spacing were $70 \mathrm{~cm}$ and $20 \mathrm{~cm}$, respectively. Superphoshate and potassium sulfate were band-fertilized at the rates of $100 \mathrm{~kg} \mathrm{P}_{2} \mathrm{O}_{5}$ and $100 \mathrm{~kg} \mathrm{~K}_{2} \mathrm{O} / \mathrm{ha}$, respectively over the experimental plots. One half of plots received $100 \mathrm{~kg} \mathrm{~N} / \mathrm{ha}$ as ammonium sulfate and another half was not applied any nitrogen fertilizer. The experiment was conducted with two replicates. The seeds were sown at the rate of one seed per hill on 21st June of 1990.

For insect control, $40 \mathrm{~g} / \mathrm{a}$ of Diazinon ( 0,0-dimethyl $O$-2-isopropyl-6-methylpyrimidin-4-yl phosphorothioate) was applied on the rows at the time of seed sowing, Methomyl (S-methyl-N-(methylcarbamoyloxy) thioacetimidatej was sprayed three times, two weeks and one week before flowering, and two weeks after flowering at the rate of 10,15 and $20 \mathrm{~g} / \mathrm{a}$, respectively, and $20 \mathrm{~g} / \mathrm{a}$ of Methomyl plus $75 \mathrm{~g} / \mathrm{a}$ of Isoxathion ‘ O,O-dietyl 0-5-phenylisoxazol-3-yl phosphorothioatej were sprayed at the pod filling stage. Plants were irrigated at flowering and pod elongation stages.

\section{Sampling}

Two plants of each replication were harvested separately at flowering and pod filling stages. After the sampling, plants were separated into leaf, stem including petiole, root, nodule and pod to measure various parameters. At maturity, five plants of each plot were harvested for measuring yield parameters. All the plant parts were lyophilized and weighed. The maturity times of the three lines were different. Bragg, nts1116 and nts1007 were harvested on 19th Nov., 13th Nov. and 8th Nov., respectively. 


\section{RESULTS AND DISCUSSION}

\section{Nodulation}

Nts mutants nodulated more abundantly than the parent $\mathrm{cv}$. Bragg at reproductive growth stages in non-N-applied plants. When nitrogen was applied, nts1007 nodulated most abundantly among these three lines, followed by Bragg and ntslll6 (Table 1). Nts1007 plants had 18 and 36 times, and ntslll6 plants had 3.2 and 0.8 times more nodule number than that of Bragg plants at flowering stage in non- $\mathrm{N}$ - and $\mathrm{N}$-treated plants, respectively. At pod filling stage, those of nts1007 were 19 and 13 times, and those of nts 1116 were 2.6 and 0.5 times more, respectively. The suppression of nodulation by nitrogen application was the severest in ntsll16 at both sampling stages, especially at pod filling stage as shown in the ratio of nodule number of $\mathrm{N}$-applied plants to that of non- $\mathrm{N}$-applied plants. In the case of Bragg, nodule number of $\mathrm{N}-$ applied plants had recovered up to the level of non-N-applied plants at pod filling stage. These results show that suppressive effect of $\mathrm{N}$-application on nodulation was longer in parent cultivar Bragg than in nts1116. Suppression effects of $\mathrm{N}$-application on nodulation of nts1007 were not remarkable.

The parent cv. Bragg showed larger nodule size than nts mutants in case of non$\mathrm{N}$-applied plants. The size of nodules decreased sharply with $\mathrm{N}$-application in case of Bragg and ntsll16 whereas in nts1007, there was no difference between N- and non$\mathrm{N}$-applied plants. Carroll et al. (1985) found the same type of tendency for nodulation of parent cultivar Bragg and nts382 (supernodulating mutant) in the presence and absence of several combined nitrogen sources.

\section{Plant dry weight}

The effects of N-application on production of dry matter of Bragg, ntsll16 and nts1007 were varied respectively at both flowering and pod filling stages (Fig. 1),

Table 1. Nodulation of nts mutants of soybean and the parent cultivar Bragg.

\begin{tabular}{|c|c|c|c|c|c|c|}
\hline \multirow{2}{*}{ Stage } & \multirow{2}{*}{$\begin{array}{l}\text { Soybean } \\
\text { line }\end{array}$} & \multicolumn{4}{|c|}{ Treatment } & \multirow{2}{*}{${ }_{*}^{+\mathrm{N} /-\mathrm{N}^{* * *}}$} \\
\hline & & Nodule number & $\begin{array}{c}\text { Nodule* } \\
\text { size }\end{array}$ & * Nodule number & $\begin{array}{r}\text { Nodule* } \\
\text { size }\end{array}$ & \\
\hline \multirow[t]{3}{*}{ Flowering } & Bragg & $47 \pm 8(1.0)^{*}$ & 5.53 & $14-\mathrm{t} \quad 12(1.0)$ & 0.71 & 0.30 \\
\hline & ntsll16 & $149 \pm 21(3.1)$ & 3.09 & $11 \pm 1(0.8)$ & 1.82 & 0.07 \\
\hline & nts1007 & $844 \pm 222(18.0)$ & 1.39 & $508 \pm 230(36.3)$ & 1.22 & 0.60 \\
\hline Pod & Bragg & $60 \pm 37(1.0)$ & 4.17 & $66 \pm 31(1.0)$ & 2.73 & 1.10 \\
\hline \multirow[t]{2}{*}{ filling } & ntsll16 & $153 \pm \quad 3(2.6)$ & 3.73 & $32 \pm 10(0.5)$ & 2.50 & 0.21 \\
\hline & nts 1007 & $1167 \pm 232(19.5)$ & 1.86 & $829 \pm 292(12.6)$ & 1.58 & 0.71 \\
\hline
\end{tabular}

* - Value in parentheses was computed by dividing the value of the nts mutants by the value of Bragg (i.e. nts1116/Bragg).

** - computed by dividing the total freeze-dry weight of nodules of cultivars by the total nodule number (mg per nodule).

*** - Ratio of nodule number of $\mathrm{N}$-applied plant to that of non- $\mathrm{N}$-applied plant. 


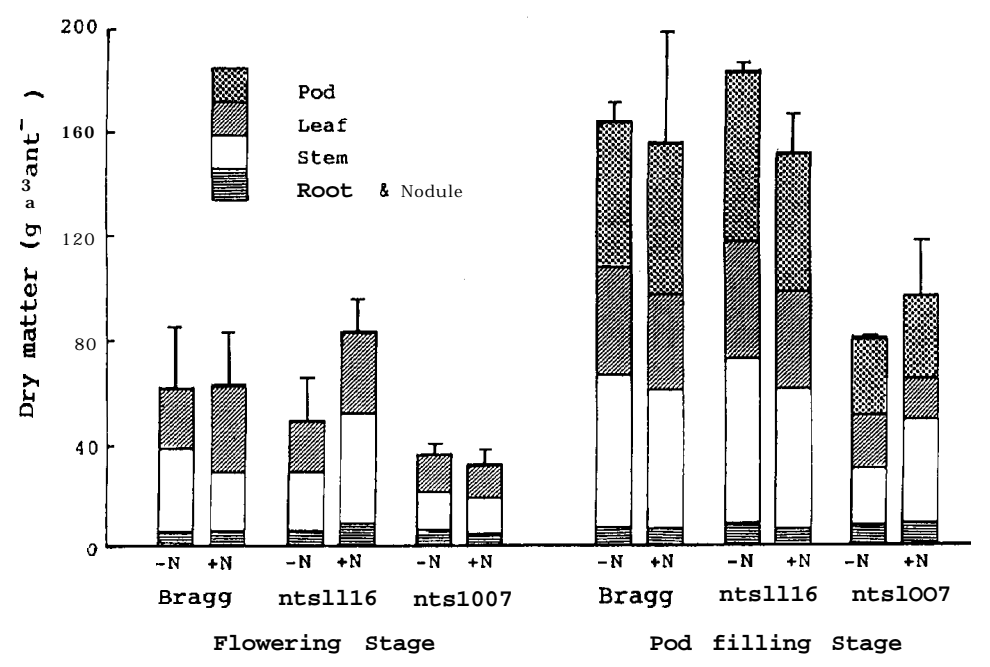

Fig. 1. Dry matter of nts mutants of Soybean and the parent cultivar Bragg.

Applied nitrogen enhanced significantly the production of total dry matter of ntsll16, but there was almost no effect of nitrogen on dry matter production in Bragg and nts1007 at flowering stage. The stem of ntsll16 contributed the main addition of weight with the nitrogen application followed by leaf. At pod filling stage, nitrogen application enhanced the production of total dry matter in nts1007, but depressed significantly in ntsll16 and had almost no effect in Bragg. From these results, it is considered that response of nts1116 to $\mathrm{N}$-application at vegetative stage was greater than that of Bragg and nts1007, and applied nitrogen was the main nitrogen source for growth because depression of nodulation by $\mathrm{N}$ fertilizer was the highest among three lines (Table 1). Therefore, due to low levels of continued biological nitrogen fixation until reproductive stage in $\mathrm{N}$-applied ntslll6 plants, dry weight of ntsll16 at pod filling stage in $\mathrm{N}$-applied plants was inferior significantly to that of non- $\mathrm{N}$-applied plants.

The mutant plants, especially the supernodulating nts1007, in growth parameters was inferior to the parent cv. Bragg. The growth of nts1007 was the least active but the leaf color was darker compared to that of the other lines. The result agrees with the experiments of Carroll et al.(1985) who used nts382 and Bragg as their test crops. Haider et al.(1991) observed in their hydroponic experiment that total dry weight of nts1116 surpassed that of nts1007 and Bragg and nts1007 was the least active.

\section{Pod number}

Table 2 shows the number of different sized pods of the three soybean lines at pod filling stage. Number of filling pods decreased significantly with nitrogen supply in ntslll6 but there were small differences in Bragg and nts1007. Large sized young pods of Bragg and ntsll16 did not vary with the nitrogen application, but in nts1007, the number was more than twice in nitrogen supplied plots than non-N-applied plots. The 
Table 2. Pod numbers of nts mutants of soybean and the parent cultivar Bragg at pod filling stage.

\begin{tabular}{|c|c|c|c|c|c|}
\hline \multirow{2}{*}{$\begin{array}{l}\text { Soybean } \\
\text { line }\end{array}$} & \multirow{2}{*}{$\begin{array}{l}\text { Treat- } \\
\text { ment }\end{array}$} & \multirow{2}{*}{$\begin{array}{l}\text { Filling } \\
\text { pod }\end{array}$} & \multicolumn{2}{|c|}{ Young pod } & \multirow[t]{2}{*}{ Total } \\
\hline & & & Large & Small & \\
\hline \multirow{2}{*}{ Bragg } & $-\mathrm{N}$ & $182 \pm 8$ & $46 \pm 8$ & $91 \pm 11$ & $319 \pm 27$ \\
\hline & $+\mathrm{N}$ & $165 \pm 36$ & $41 \pm 13$ & $74 \pm 28$ & $280 \pm 78$ \\
\hline \multirow{2}{*}{ nts1116 } & $-N$ & $168 \pm 1$ & $53 \pm 4$ & $49 \pm 3$ & $270 \mathrm{f} 5$ \\
\hline & $+\mathrm{N}$ & $138 \pm 20$ & $54 \pm 13$ & $18 \pm 1$ & $210 \pm 7$ \\
\hline \multirow{2}{*}{ nts1007 } & $-N$ & $98 \pm 1$ & $21 \pm 4$ & $45 \pm 15$ & $164 \pm 18$ \\
\hline & $+\mathrm{N}$ & $83 \pm 13$ & $48 \pm 6$ & $32 \pm 1$ & $163 \pm 18$ \\
\hline
\end{tabular}

Table 3. Yield parameters of nts mutants of soybean and the parent cultivar Bragg

\begin{tabular}{lccccc}
\hline $\begin{array}{l}\text { Soybean } \\
\text { line }\end{array}$ & $\begin{array}{c}\text { Treat- } \\
\text { ment }\end{array}$ & $\begin{array}{c}\text { Grain } \\
\text { yield(G) } \\
(\mathrm{t} / \mathrm{ha})\end{array}$ & $\begin{array}{c}\text { Total dry* } \\
\text { matter(T) } \\
(\mathrm{t} / \mathrm{ha})\end{array}$ & $\begin{array}{c}\text { Harvest } \\
\text { index } \\
(\mathrm{G} / \mathrm{T})\end{array}$ & $\begin{array}{c}100 \\
\text { seeds } \\
\text { weight(g) }\end{array}$ \\
\cline { 1 - 3 } Bragg & $-\mathrm{N}$ & $3.9 \pm 0.1$ & $6.7 \pm 0.1$ & 0.58 & $19.5 \pm 0.1$ \\
& $+\mathrm{N}$ & $3.3 \pm 0.2$ & $6.4 \pm 0.1$ & 0.52 & $18.9 \mathrm{t} 0.3$ \\
nts1116 & $-\mathrm{N}$ & $3.3 \mathrm{f} 0.5$ & $5.6 \mathrm{f} 0.4$ & 0.60 & $18.2 \pm 0.5$ \\
& $+\mathrm{N}$ & $3.0 \mathrm{f} 0.3$ & $6.0 \pm 0.1$ & 0.51 & $18.3 \mathrm{i}-0.2$ \\
nts1007 & $-\mathrm{N}$ & $2.2 \pm 0.1$ & $3.8 \mathrm{ff} 0.2$ & 0.59 & $18.2 \mathrm{k} 0.0$ \\
& $+\mathrm{N}$ & $2.4 \pm 0.1$ & $4.2 \pm 0.3$ & 0.58 & $18.4 \mathrm{fo} 0.6$ \\
\hline
\end{tabular}

*- Total dry matter is composed of grain, pod shell and stem.

number of small sized young pods decreased in ntslll6 with nitrogen application, and Bragg and nts1007 did not show so remarkable decrease as nts1116. The total number of pods at pod filling stage of ntslll6 decreased significantly with the nitrogen application but in case of nts1007 and Bragg, the reduction with $\mathrm{N}$-application was not remarkable. In both $\mathrm{N}$ - and non- $\mathrm{N}$-applied plots, the greatest pod number was obtained in Bragg and smallest in nts1007. The mutant plants were not superior to the wild-type parent cultivar in growth and yield 'as shown by Carroll et al.(1985).

\section{Yield parameters}

As shown in Table 3 total dry matter (TDM) and grain yield were the greatest in Bragg followed by nts1l16 in regardless of N-application, and smallest in nts1007. Ishizuka $(1972,1977)$ reported that the cultivar which continued to grow vigorously after the flowering stage had dropped out considerable immature pods which might reflect competition of pods for certain metabolites with the growing vegetative tissues. The results as concerned with ntslll6 show that the vegetative growth in ntsll16 was continued until pod filling stage, and pod formation was depressed. At maturity, TDM and grain yield of Bragg decreased when nitrogen was applied. In nts1116, N-applied plants showed higher values of TDM and lower values of grain yield than non-Napplied plants. Both grain yield and TDM production of nts 1007 were increased by $\mathrm{N}$ application. There were no remarkable variation in 100 seeds weights of the three soybean lines. The harvest index of both parent cultivar Bragg and nuts1116 decreased with nitrogen application, whereas the reverse trend observed in nts1007. Applied 
nitrogen might enhance the vegetative growth of both Bragg and nts1116 excessively, disturb the pod-setting, and hence depress the yield. As a result, yield indexes of Bragg and ntsll16 decreased with the application of nitrogen. On the contrary, in case of nts1007, nitrogen application did not accelerate excessively vegetative growth of plants, and did not result in decrease of harvest index. These results show that in the parent $\mathrm{cv}$. Bragg and hypernodulating mutant ntsll16, nitrogen application at the rate of $100 \mathrm{~kg} / \mathrm{ha}$ do not improve the yield and growth parameter, because applied nitrogen depressed severely nodulation in both the plants (Table 1). However, in nts1007 plants, nitrogen application did not disturb the yield parameter such as harvest index (Table 3 ). This give us the possibility that if the vegetative growth is further improved by way of early sowing and greater amounts of applied nitrogen, the yield of nts 1007 will be increased, because supernodulating mutant nts 1007 is not severely suppressed for nodulation by a large amount of nitrogen applied and does not perform excessively accelerated vegetative growth.

\section{REFERENCES}

Carroll, B. J. and P. M. Gresshoff 1983 Nitrate inhibition of nodulation and nitrogen fixation in white clover. Z.Planzenphysiol., 110: 77-78

Carroll, B. J., D. L. McNeil and P. M. Gresshoff 1985 Isolation and properties of soybean (Glycine max L.) mutants that nodulate in the presence of high nitrate concentrations. Proc.Natl.Acad. Sci. USA, 82: $4162-4166$

Delves, A. C., A. Mathews, D. A. Day, A. S. Carter, B. J. Carroll and P. M. Gresshoff 1986 Regulation of the Rhizobium-soybean symbiosis by shoot and root factors. Plant Physiol.. 82: 588590

Eastin, E. F. 1978 Total nitrogen determination for plant material containing nitrate. A nal. Biochem., 85: 591-594

Gresshoff, P. M., D. A. Day, A. C. Delves, A. Mathews, J. E. Olsson, G. D. Price, K. A. Schuller and B. J. Carroll 1985 Plant host genetics of nodulation and symbiotic nitrogen fixation in pea and soybean. In "Nitrogen Fixation Research Progress" ed. by H. J. Evans, P. J. Bottomley and E. E. Newton, Martinus Nijhoff Publishers, The Hagve pp. 19-24

Haider, J., A. K. M. A. Hussain, M. Ikeda, T. Yamakawa and J. Ishizuka 1991 Effects of nitrate application on growth, nodulation and nitrogen fixation of nitrate-tolerant mutants of soybean. Soil Sci. Plant Nutr., 37: 521-529

Ishizuka, J. 1972 Physiological roles of soluble nitrogenous components on vegetative growth and seed protein formation of soybean plants in Hokkaido. Res. Bull. Hokkaido Natl. Agric. Exp.Stn., 101, 51-121

Ishizuka, J. 1977 Function of symbiotically fixed nitrogen for grain production in soybean. In "Proceedings of the Intemanational seminar on Soil Environment and Fertility Management in Intensive Agriculture", Soc. Sci. Soil Manure Japan, Tokyo, pp. 618-624

Streeter, J. G. 1981 Effect of nitrate in the rooting medium on carbohydrate composition of soybean nodules. Plant Physiol., 68: 840-844

Truog, E. 1930 The determination of the readily available phosphorous of soils. J. Am. Soc. Agron., 22: $874-882$ 